Saudi Journal of Humanities and Social Sciences

Abbreviated Key Title: Saudi J Humanities Soc Sci

ISSN 2415-6256 (Print) | ISSN 2415-6248 (Online)

Scholars Middle East Publishers, Dubai, United Arab Emirates

Journal homepage: http://scholarsmepub.com/sihss/

Original Research Article

\title{
Determinant Factors Affecting the Community Empowerment Implementation Program in Wajo Regency
}

\author{
Andi Mamu*, Rakhmat, Muhammad Yunus, Atta Irene Allorante \\ Department of Public Administration, Faculty of Social and Political Sciences, Hasanuddin University Indonesia
}

DOI: $\underline{10.36348 / \mathrm{sjhss} .2019 . \mathrm{v04i12.003}}$

| Received: 07.12.2019 | Accepted: 16.12.2019 | Published: 20.12.2019

*Corresponding author: Andi Mamu

\section{Abstract}

One of the problems related to national issues in Indonesia is the improvement of community welfare; this has encouraged the government to maximize the village community empowerment program. This study aims to analyze the determinant factors affecting the community empowerment implementation program in Wajo Regency. This research is a qualitative research that aims to analyze a phenomenon and activity in implementing the empowerment policy implementation in Wajo Regency. Data collection strategies that have been carried out are: observation, interviews, document studies, and Focus Group Discussions (FGD). The results showed that policy implementation was determined by the determinant factor, which consisted of the policy environment as a determinant factor, such as the power, interests and strategies of the actors involved the characteristics of the institutions and authorities of Compliance and responsiveness of the implementers.

Keywords: Program Implementation, Community Empowerment, Villages.

Copyright @ 2019: This is an open-access article distributed under the terms of the Creative Commons Attribution license which permits unrestricted use, distribution, and reproduction in any medium for non-commercial use (NonCommercial, or CC-BY-NC) provided the original author and source are credited.

\section{INTRODUCTION}

Generally, people crave ideal conditions related to a prosperous life structure both physically, economically, and environmentally. This condition describes a life where the needs of the community can be met. In addition it leads to stable conditions that are not disturbed by security instability about the future, a life that provides a conducive atmosphere that reflects social justice for all people [1].

One of the problems that became a national issue in Indonesia is a matter of improving the welfare of the community, especially in the Village; therefore, efforts are needed in the context of poverty alleviation in the Village through various programs that can be carried out by the government, one of them through the empowerment program in the Village [2].

After publication of Law No. 6 of 2014 concerning Villages has had a strong dynamic impact on the management of village governance. Villages are demanded to improve their well-being by giving a certain amount of authority in managing resources to improve village welfare in terms of infrastructure and village human resources.
One of the supporting factors in order to encourage empowerment is the role of the government itself. The extent of support provided by the government both from the national level to the level of local government, so that the effectiveness of empowerment [3].

Policy implementation is determined by determination factor, which consists of the policy environment to be a determinant factor, such as the power, interests and strategies of the actors involved the characteristics of institutions and authorities of compliance $\&$ responsiveness of implementers $[4,5]$. In the field, the social environment is a catalyst for policy implementation. The social environment can accelerate the realization of a policy, but on the other hand it can also hamper policy implementation. The interrelationship between the social environment, especially policy actors is the driving force that greatly impacts the implementation of empowerment policies in Wajo Regency. This study aims to analyze the determinant factors affecting the community empowerment implementation program in Wajo Regency. 


\section{METHODOLOGY}

This research is a qualitative research that aims to analyze a phenomenon and activity in implementing the empowerment policy implementation in Wajo Regency. The research has been carried out in a research setting in several villages in the District of Pitfeedua including Lagoari Village, Parigi Village, Wewangrewu Village, Nepo Village, Batu Village, and Jauhpandang Village.

Sources of data through informants in this study were conducted purposively. In the context of this research, there are several data collection strategies that have been carried out, namely: observation, interviews, document studies, and Focus Group Discussion (FGD). Data analysis is performed through data reduction, data display, and conclusion drawing.

\section{RESULTS AND DISCUSSION}

\section{The Power, Interests and Strategy of the Actors Involved}

The dynamics of village governance are strongly felt in the post-reform era which explicitly gives the village democratic space and has implications for the political position of the village head. This democratic space has provided an opportunity for village elites to be able to contest democratically. In order to obtain a mandate from the villagers in managing the village administration and resources. It aims to build and realize the welfare of the village community.

The democratization that took place in the Wajo district area has actually provided implicit support for the welfare improvement program in the villages under the Wajo district government area. One manifestation of the program is empowerment that directly targets rural communities both in disadvantaged areas and urban villages.

In realizing a good implementation of the Wajo district government program needed capable human resources in running the government. Including bureaucratic structures that perform public services to the community should be sufficiently capable in carrying out bureaucracy.

Table-1: Analysis of performance Indicators of work Improved quality of employment administration services

\begin{tabular}{|l|c|c|c|c|c|c|}
\hline \multicolumn{1}{|c|}{\begin{tabular}{c}
\multicolumn{1}{c}{$\begin{array}{c}\text { Performance } \\
\text { indicator }\end{array}$} \\
\cline { 2 - 7 }
\end{tabular}} & Target & Realization & Target & Realization & Target & Realization \\
\hline $\begin{array}{l}\text { Staffing } \\
\text { administrative } \\
\text { service satisfaction } \\
\text { index }\end{array}$ & 55 & 57 & 60 & 88,74 & 65 & 83,23 \\
\hline $\begin{array}{l}\text { Achievement of } \\
\text { performance } \\
\text { indicators }\end{array}$ & & & & & & \\
\hline
\end{tabular}

Source: Wajo Regency BKPSDM performance report for 2017

Based on the data in table 1, the performance of the Wajo district government has generally made improvements in the public service sector to the community. Achievement of targets regularly shows a significant increase based on this percentage. Thus it can be assumed that the process of running the government is quite good in the Wajo district.

This certainly becomes the main capital for the Wajo district government in carrying out policies in the Wajo region. In the village context, there has been a dynamic in the implementation of village governance in recent years. Exactly after the issuance of the Law on Villages which gave more authority to the Village in managing the Village budget. The budget received by each village can be managed autonomously so that this authority creates dynamics that have implications for the democratization process in the village.

In the pre-existing allocation fund for the Village, it was recognized that there were many difficulties that arose in managing the village administration. Villages are only able to pin their hopes on the local government or even the central government through the PNPM program. This was said by almost all village community leaders namely Lagoari Village, Parigi Village, Wawanrewu Village, Nepo Village, Batu Village and Jauh Pandang Village.

The dependency that arises is recognized by many authorities in the regions in regulating the distribution of resources that will be given to villages. This presents a particular challenge for the Village apparatus in order to be able to make a good approach to the local authorities at that time to get the allocation of resources. The implication will provide a very strong influence on the existence of regional leadership power at that time.

After the issuance of village law is a breath of fresh air for the current village government. Financial capacity can slowly be managed independently by the Village slowly. Although in addition, there are still villages that get assistance sourced from outside the village funds. Both assistance in the form of physical equipment and in the form of rupiah. 
In the context of Wajo district, the assistance received by the villages varies greatly. As happened in the Takalalla sub-district, which includes Parigi and Lagoari villages. There was a significant difference between the two villages, Parigi village received more physical assistance from various sources such as direct assistance from South Sulawesi Province, the Central Government and even international assistance, namely Japan.

Such conditions certainly provide a lot of convenience for the village to improve the welfare of its citizens. Among the very useful assistance are clean water and biogas that can meet the needs of the community's kitchen and be more efficient, and in the field of community empowerment is training in traditional village cloth weaving techniques. This is very helpful for housewives in carrying out efficient household routine expenditure (Interview with Ms. Nurlaila Arif on July 25, 2019, as one of the hamlet heads in Parigi Village, Takalalla sub-district, Wajo).

In contrast to the condition of Parigi village, Lagoari village is one of the villages that has quite minimal assistance. Most of the village's expectations are based only on the village budget. This causes the village situation to be more difficult to develop compared to the village of Parigi which has more resource assistance.

This condition has negative implications, namely the lack of distribution of resources to each village in the Wajo district. Lack of attention to the provision of assistance, village community assistance provides its own difficulties for residents who still have limitations.

One of the problems with the unequal distribution of resources is the influence of power that has an affiliation with the village itself. This causes Lagoari village to have political obstacles so that it feels more difficult to get help outside of the village funds. Political affiliation developed between the village and the authorities turned out to have a significant impact on the development of the village community. A single expectation on the allocation of village funds is deemed insufficient to meet the needs of the village and the conditions of villagers who are still not innovative in managing the village funds.

In terms of policy context, the amount of assistance obtained by Parigi villagers is none other than because Parigi village has political affiliation with regional authorities. This affiliation is in the form of emotional affiliation because the village of Parigi is part of the hometown of the Deputy Governor of South Sulawesi. This has an impact on how easily the local government assistance is well distributed in this village. Thus, the context is still needed as a region and time so that the desired changes from policies that have been designed in the policy content can be implemented properly in accordance with the objectives of the policy [6]. The process of unequal distribution of resources in Wajo can be said to be influenced by political structures that do not accommodate the needs of society as a whole.

Communication between actors in the village implementor with the political structure on it does not run as a whole. So that the stratregi implementation of the game against the actor cannot afford his desire accommodated in the implementation of the policy. Especially related to the empowerment policy in the village.

In addition, there are urban category villages that have their own characteristics in maximizing the implementation of empowerment policies in the village. This can be seen in the Tanasitolo sub-district, which includes the Nepo village, which is the closest geographical area to the city center and the district government of Wajo. Basically the success achieved by the Nepo village is the impact of the establishment of the economic conditions of the village.

This is due to positive innovations from the village apparatus in managing village finances. The majority of village financial resources come only from the budget of the village fund itself. The form of innovation carried out was by establishing BUMDes with various business units owned and aimed at increasing the village's original income itself.

The creative attitude taken by the village apparatus is one of the solutions in managing and improving village finances. So the village will be more independent to determine what policies can be implemented effectively and in accordance with the needs of the local community. This is very positive considering that with the existence of good human resources in village management, the difficulties of the village community can be given a gradual solution.

The people of Nepo Village have a variety of different professional backgrounds ranging from fishermen, farmers, woven cloth craftsmen to public and private employees, given the location of the Village is still in a category very close to urban life. Although factually it is still dominated by fishermen and farmers and a small portion of woven fabric craftsmen.

\section{Characteristics of Institutions and Regimes in Power}

The institutional style can provide a picture of the pattern of relations between state and society. State capacity is closely related to the authority possessed in the context of policy making and budgeting. Whereas the community is more positioned as a social network that can be mobilized [7]. 
Problems that occur on the ground, especially in the Takkalalla sub-district area, explain that one of the unrest or disapproval of the community in terms of government policies is not on target. In the village, of course, they are already very familiar with various village escort officers, especially $\mathrm{PKH}$ which is the Ministry of Social Affairs program.

This happened in the village of Lagoari, PKH employees who under the coordination of the Ministry of Social Affairs had never coordinated with village officials regarding the program's policy objectives. The invalidity of the data they use has implications for the inaccurate targeting of aid-rocks originating from the Ministry of Social Affairs itself.

Sometimes even those who subscribe to social assistance target groups that are categorized as wellestablished or capable in the village. As a result, other residents who are still in the category of shortage actually do not get social assistance.

This has become a problem for the village community; the apparatuses have tried to protest against related parties. However, communication between the two parties did not go well. Villagers even suggested that in the future PKH officers should be recruited based on domicile only because they were considered to be better able to understand the actual condition of the village.

The village facilitators in carrying out their duties did not do a thorough data collection and updates. Resulting in the provision of assistance programs that are not on target. So that it cannot accommodate villagers who should be included in the category of residents who get help.

Lack of communication and coordination between the village apparatus and PKH assistants has led to a prolonged conflict with the social service reference data used as a basis for determining policy targets in the village. So that the policy implementation process can run less optimally.

Thus there is a top-down policy pattern that will limit the independence and involvement of the community in every detail of policy implementation. This pattern will have an unfavorable impact on policy target groups. This pattern tends to be centralized by only relying on one-sided data without going directly to the community to map the effectiveness of the policy to be carried out.

Therefore, the Wajo district government should continue to pay equal attention to all villages in the Wajo district. Conducting public services by hearing all input from various parties including villagers at the lowest level so that policy mapping can be maximized.
The top-down pattern has a weakness that is not able to reach in detail the needs at the grassroots level. Therefore, the potential for conflicts that occur is quite likely to occur. This was the complaint of Lagoari villagers because the policy program in the form of assistance was actually given to people who were welloff in the village. While residents who are categorized as not able to even get no help at all (Interview with $\mathrm{Mr}$. Kaharudin on July 25, 2019, as chairman of BPD Lagoari Keacamatan Takalalla, Wajo). Public unrest as it should be input for the government to be a concern. So that public services for the welfare of the village get a bright spot.

The attitude of the community that has tended to be participatory in voicing their concerns, the real problems in the village should make it easier to identify the problems that exist in the villages. So that local governments can easily provide the right solution.

Therefore, a new pattern is needed, namely bottom up where the community can be involved from the beginning in the process of implementing policies to determine the community's needs of the community towards a policy product. This pattern will further strengthen the latest data on the right policy targets according to conditions in the community.

Thus, various conflict cases that occur in the village, especially related to data errors that lead to policies that are wrongly targeted. Updating the data that is the target group needs to be done to create an effective policy implementation in the community.

\section{Compliance and Responsiveness}

The level of participation of villagers varies greatly in responding to policies that will be carried out in the village, especially the issue of empowering village communities. The role of community participation is very important in responding to policies, indicators of community acceptability can be one of the benchmarks in assessing whether the implementation is on track or not.

In this context, researchers classify the forms of responsiveness that exist in villages in the Wajo district. The classification can be divided into 2 parts, namely, first the responsiveness of the community category of urban villages, and secondly the responsiveness of the community category of villages far from the city center.

In the context of urban villages, as happened in Nepo village as a village that has a variety of different professional backgrounds in society. In addition, urban characteristics also pose a challenge for villages in gaining participation in implementing community empowerment policies. 
The close interaction with urban areas has various kinds of effects on the village, ranging from culture issues to business competition issues. So that villagers are required to be more competitive in facing various challenges in the development of the Village. This will feel very different if you look at the rural conditions far from urban areas. The composition of the people who tend to have a common background makes it easy for them to be able to get involved in participating in empowerment programs in the village.

Various village programs can be carried out together with the spirit of building the village itself. Such as village infrastructure that facilitates citizens' access to skills training in various fields according to the needs of the local community. The condition of people who still lack skills provides an advantageous position to the community with the empowerment program. Very different from typical communities in urban villages that already have skills abilities with their livelihoods that are so diverse that it will be difficult to spend time on the empowerment program.

One village that has good responsiveness in the Wajo district is Batu village. The Village Community Empowerment / Community Development Sector almost entirely, the absorption of Batu's village budget shows a good value presentation of $100 \%$, with the total budgeted funds for this field amounting to Rp.70,593,403 during 2018 but Batu Village is included in the calculated Village category new in carrying out empowerment programs in the community. So that the previous year there were no reports that showed an empowerment program.

All of the above activities have become the agenda of empowering Batu Village. This shows that the focus of the Batu Village empowerment program is to improve the welfare of both the Village community and the Village apparatus. Very different in the period before the Village Fund assistance, the village government could only expect more assistance from external villages to carry out village activities or programs.

In addition, with the assistance of the Village Fund, the village government of Batu also strengthened the Village-Owned Enterprises (BUMDes). One of the efforts made by village leaders is to provide regular understanding to the community. The effort is to call for the participation of rural communities to succeed in the implementation of various policy programs in the village, including policies related to community empowerment. Public understanding of the policies that have been formulated will affect the responsiveness of the community in responding to policies properly.

The good level of participation of rural communities would certainly correlate with the theory which assumes that the higher the acceptability and participation in the community, the better the performance of the policy. Conversely, the lower the level of acceptability and participatory village communities or in other words there is rejection by target groups and tends to be passive, it will tend to give birth more failure in implementation.

The empowerment policy implementation process in Wajo district has quite a variety of complexity. Therefore, researchers need a variety of concepts both in content policy and policy context. Grindle assumptions can pretty much explain the problematics of the policy failing to be implemented properly.

Failure to implement policies specifically for community empowerment can occur due to various factors. Factors of economic and political conditions to the pattern of community participation that is not ideal $[8,9]$. This has been proven in some cases in villages especially those that are far from the reach of the regional government or the regional government center.

The condition of the people who are less competent in managing the village is also a serious problem. As a result there is no initiation that can be done in order to develop people in the village. Residents can only wait for what can be done by the village government to increase the capacity of its citizens to be more prosperous.

In the context of this research, of course it can also show villages that are quite successful in carrying out policy implementation in the village. In particular the village of Parigi which had success was due to political supporting factors. Funds will look very different from neighboring villages that do not have the same program as Parigi villages.

In addition, there are other categories that indicate the success of villages in the process of implementing policies in the villages, namely urban villages. The interesting thing about urban villages is the limited budget of the village, and without getting the distribution of resources from the authorities but still able to implement policies properly [10]. Economic independence will greatly affect the process of implementing existing policies in the village [11]. The difficulty of political affiliation to get resource assistance is not a significant obstacle in implementing policies. Villages can still carry out empowerment programs optimally by recognizing the needs of village communities [12]. Therefore, it takes qualified human resources (HR) in managing the village. Competitive human resources tend to be able to rely on internal strategies in meeting the policy programs run by the village. In addition, the village also does not have a very high dependence on political factors in the context of implementing policies in the village. 


\section{CONCLUSION}

Policy implementation is determined by the determination factor, which consists of the policy environment to be a determinant factor, such as the power, interests and strategies of the actors involved, the characteristics of the institutions and authorities of Compliance \& responsiveness of the implementers. In the field, the social environment is a catalyst for policy implementation. The social environment can accelerate the realization of a policy, but on the other hand it can also hamper policy implementation. The interrelationship between the social environment, especially policy actors is a driving force that greatly impacts the implementation of empowerment policies in Wajo.

\section{REFERENCES}

1. Power, E. M. (1999). Combining social justice and sustainability for food security. For hunger-proof cities: sustainable urban food systems. Ottawa: International Development Research Centre, 30-7.

2. Ito, T. (2006). The dynamics of local governance reform in decentralizing Indonesia: Participatory planning and village empowerment in Bandung, West Java. Asian and African Area Studies, 5(2), 137-183.

3. Muljono, P. (2013). The role of posdaya in shaping community empowerment: Case study at Cikarawang village, Bogor, Indonesia. Asian Journal of Humanities and Social Studies (ISSN: 2321-2799), 1(05).
4. Thomas, J. W., \& Grindle, M. S. (1990). After the decision: Implementing policy reforms in developing countries. World development, 18(8), 1163-1181.

5. Brynard, P. A. (2009). Mapping the factors that influence policy implementation. Journal of Public Administration, 44(3.1), 557-577.

6. Meyers, M. K., Vorsanger, S., Peters, B. G., \& Pierre, J. (2007). Street-level bureaucrats and the implementation of public policy. The handbook of public administration, 153-163.

7. Painter, M., \& Pierre, J. (Eds.). (2004). Challenges to state policy capacity: Global trends and comparative perspectives. Springer.

8. Wilensky, H. L. (2002). Rich democracies: Political economy, public policy, and performance. Univ of California Press.

9. Holzinger, K., \& Knill, C. (2005). Causes and conditions of cross-national policy convergence. Journal of European public policy, 12(5), 775796.

10. Hao, P., Geertman, S., Hooimeijer, P., \& Sliuzas, R. (2013). Spatial analyses of the urban village development process in Shenzhen, China. International Journal of Urban and Regional Research, 37(6), 2177-2197.

11. Magnaghi, A. (2005). The urban village: a charter for democracy and sustainable development in the city. Zed books.

12. Arensberg, C. M. (2017). Introducing social change: A manual for community development. Routledge. 